\title{
OS TUPINAMBÁS E OS PAPAGAIOS AMARELOS OU AS RELAÇÕES ENTRE BRASIL E FRANÇA ENTRE OS SÉCULOS XVI E XVII
}

Mary Del Priore

FFLCH/USP

"- Você falou-me em Roldão...

Conhece dos Cavaleiros, Dos Doze Pares de França, Dos destemidos guerreiros?

Falaras-me alguma coisa De Roldão mais Oliveiros"

Desafio dos cantadores Manuel Serrador e Josué Romano, no Ceará, registrado por Leonardo Mota em Cantadores, (1921)

Resumo: Este texto trata das visões produzidas pelos exploradores franceses no seu contato com as gentes e as terras do Brasil nos primórdios da colonização européia.

Unitermos:Viajantes, História do Brasil, Colonização, Representações.

Imaginemos a cena. Sexta feira, 12 de abril de 1613, uma pequena multidão se acotovelava na entrada do faubourg SaintHonoré a espera de uma centena de padres capuchinhos do convento da Paris. Na animação da rua, formara-se uma barulhenta procissão que, cantando, se aproximou das portas do dito convento. $\mathrm{Ai}$, a aguardava um grupo de nobres desejosos de demonstrar seu entusiasmo face ao que era considerado uma "santa e feliz conquista". Mas não só. Estavam todos igualmente curiosos de conhecer "esses pobres selvagens revestidos de suas mais belas plumagens, maracas à mão". A 
aglomeração, nessas alturas, era tão volumosa que o cortejo teve dificuldade em penetrar na igreja. Uma fila de padres tentava isolar o grupo de estrangeiros semi nus dos aristocratas, sobretudo, "princesas, damas e outras pessoas de mérito" que se espremiam, na ponta dos pés, tentando enxergar melhor os embaixadores do Novo Mundo. Foi o assunto social da semana.

Três dias depois, os tupinambás, já vestidos à francesa, foram se encontrar com a rainha, Maria de Médicis, no palácio do Louvre. Em frente à sua alteza, executaram uma dança sem grandes movimentos, ritmada apenas por instrumentos, provavelmente chocalhos, contendo, no entender de um observador, "pregos". Enquanto os companheiros exibiam seus dotes musicais, o índio Itapucu fez um discurso em sua língua natal, pedindo ao rei para enviar ao Maranhão mais profetas referia-se aos padres capuchinhos - e outros tantos grandes guerreiros, prometendo fidelidade aos seus amigos "papagaios amarelos" - como eram chamados os franceses ${ }^{1}$. A uma senhora desejosa de saber o que mais lhe agradara na França, um dos índios respondeu sem hesitar: "as mulheres". E outra que, em tom zombeteiro, Ihe perguntou se achava as de sua terra mais bonitas que as francesas, recebeu logo o troco: "Ainda não podemos julgar, respondeu o índio. "só diremos a verdade quando pudermos ver as daqui inteiramente nuas, assim como costumamos ver as de nossa terra"2. O rei Luís XIII, um menino de temperamento secreto e tímido, visivelmente emocionado, prometeu tratá-los como aos seus próprios súditos enquanto a rainha lhes garantia ajuda e defesa.

Foi assim, entre risos e festas, o primeiro contato entre

\footnotetext{
1 Empresto essas informações a Maurice Pianzola e seu Des français á la conquête du Brésil - les perroquets jaunes, Paris, L'Harmattan, 1991, pp.23-24.

2 Apud Sérgio Buarque de Holanda, , "Os franceses no Maranhão", in História Geral da Civilização Brasileira, Rio de Janeiro, Difel, 1976, tomo I, A Época Colonial, p.224.
} 
franceses e brasileiros? Não. Cinqüenta anos antes, numa Rouen arruinada e ainda fumegante dos cruéis embates nascidos das guerras entre católicos e protestantes, Michel de Montaigne, um dos maiores escritores do Renascimento tentava entrevistar um grupo de canibais recém-chegados da Terra de Santa Cruz. Os índios se encontravam visivelmente embaraçados com a desordem que descobriram nessa Europa tão civilizada, a qual os missionários não paravam de elogiar durante a travessia. Infinitas atenções e delicadezas Ihes foram dispensadas. O rei os recebeu pessoalmente e lhes falou durante um longo tempo. Desenrolaram-se aos seus olhos a magnificência do cortejo real, a pompa da corte em movimento e o que sobrara de uma bela cidade depois de um violento cerco que durara meses. Longe da admiração que deles se esperava, os indígenas só conseguiam expressar espanto! Para começar, não ocultavam o desprezo pela idade do rei, então Carlos IX, também menino pois perdera seu pai recentemente. Impressionamse ainda mais com a vizinhança entre ricos e pobres perguntando-se como estes últimos podem se permitira uma tal injustiça, sem esganar os outros ou botar fogo em suas casas ${ }^{3}$.

Montaigne, por sua vez, insistiu na entrevista. Suas perguntas, diferentemente daquelas que lhe tinham sido formuladas pelo rei, eram todas de cunho político, como se ele tivesse aceitado colocar-se do lado dos canibais, tornando-se, por assim dizer, uma espécie de seu porta-voz. Sua curiosidade referia-se, com efeito, à natureza da função monárquica entre os selvagens. Quais seriam os privilégios do rei no Brasil? "Aquele de marchar em primeiro lugar para a guerra", Ihe foi respondido. - A quantos homens monta seu exército? - Quatro ou cinco mil, tanto quanto possa caber no "espaço de um lugar" designado por um amplo gesto do interlocutor que era chamado

\footnotetext{
${ }^{3}$ Todas estas informações extraídas de Franck Lestringant, Le cannibale: grandeur et décadence, Paris, Plon, 1992. A obra teve uma tradução minha com o título $O$ canibal, grandeza e decadência, DF, EDUNB, 1997, p.10.
} 
por Montaigne de capitão. -Além da guerra, no que reside sua autoridade? - Quando ele visita as cidades de sua jurisdição, abrem-se-Ihe "picadas através da mata para que ele possa passar confortavelmente". Nesse outono de 1562, as palavras do selvagem vindo do outro lado do Atlântico serviam para denunciar as injustiças numa cidade arrasada pela guerra e onde os indigentes pululavam.

O interessante é que na época em que este diálogo se realizou, alguns franceses conheciam perfeitamente certos trechos da costa brasileira. Vindos da Normandia e da Bretanha, entrelopos e corsários faziam comércio freqüente de pau-brasil, pimenta da terra e algodão com nossos indígenas. Alguns deles optaram por viver entre as tribos. Desde a boca do Amazonas até o costa catarinense esses ativos traficantes eram vistos, agindo impunemente e sem disfarces. Áreas mais procuradas, como as do cabo de São Roque ao Rio Real eram aquelas onde o pau de tinta era mais facilmente extraído. Ousados, os chamados "papagaios amarelos", - por causa da fala e da cabeleira loura -, aliaram-se com os índios em algumas regiões, para desafiar os portugueses. Foi assim na Paraíba, em Sergipe e no Ceará, onde Pero Coelho teve que travar feroz luta contra a taba de Mel Redondo, na qual tabajaras e franceses viviam em harmonia 4 . Outros franceses mais atrevidos, levavam suas incursões até as capitânias situadas ao sul da Bahia de Todos os Santos, bloqueando a atividade de moradores e engenhos até terminar de carregar suas naus ${ }^{5}$. Em Cabo Frio, no Rio de Janeiro, fizeram aliança com os tamoios, insurgidos contra os portugueses, fazendo-os encher seus navios com pássaros, macacos além do indefectível pau-brasil. Ali deixaram marinheiros que aprenderam a língua nativa, capazes também

\footnotetext{
${ }^{4}$ R. Batista Aragão, História do Ceará, 2 volumes, Fortaleza,s/e,s/d, tomo I, p.28 ${ }^{5}$ Emprestarei a seguir informações a Sérgio Buarque de Holanda, "Franceses, holandeses e ingleses no Brasil Quinhentista", in op.cit.p.147 e passim.
} 
de organizar o embarque de mercadorias tão logo as naus, vindas do outro lado do Atlântico, aportassem às praias ${ }^{6}$.

Até 1555 , era assim que agiam os franceses. Práticos, preferiam tratar e negociar diretamente com a gente da terra. Conhecendo os melhores abrigos, portos naturais e sítios onde podiam encontrar água e alimentos, não pareciam querer construir fortes ou feitorias á maneira dos portugueses. $O$ importante era manter boas relações e a constância nas trocas comerciais. Esse comércio pontual de pequena e média escala funcionou tão bem que deixou marcas. Um exemplo? O armador e flibusteiro Jean Ango, protegido do rei Francisco I, teve o seu barco o Espoir, lançado, por uma tempestade, em 1503, ao litoral do Brasil. Começava, assim, uma relação complexa cujo cenário passamos a descrever ${ }^{7}$.

Os portugueses, ancorados no que parecia um direito inalienável, faziam valer sua hegemonia nas novas terras e mares recém descobertos. Uma bula papal Ihes dava posse, como aos espanhóis das terras descobertas de um lado e outro do globo. Era o famoso Tratado de Tordesilhas que dividia o mundo em dois. Enquanto isso, o rei francês, Francisco I, não se cansava de criticá-lo: "Eu gostaria de saber - queixava-se qual a cláusula do testamento de Adão que me exclui da partilha do mundo. O sol não brilha para mim como para tantos outros.?". Em 1522, o rei João III ordenou que seus capitães afundassem, sem misericórdia alguma, as naves francesas encontradas nas Índias da América. Entre os dois países nascia uma guerra surda, porém atroz. Uma pequena colônia fundada pelo Barão de Saint-

\footnotetext{
${ }^{6}$ Informação do Brasil e de suas capitanias, 1584, oferecido de Lisboa pelo sócio sr. Varhagen. Revista do Instituto Histórico e Geográfica Brasileiro, vol.VI, Rio de Janeiro, 1844.

7 Sobre o assunto ver o meu artigo, "Selvages en la iglesia, el friso de SaintJacques de Dieppe: un caso de bricolage cultural", in Entre dos mundos: fronteras culturales y agentes mediadores, (org.) Berta Ayres e Serge Gruzinski, Sevilha, Escuela de Estudios Hispano-americanos, Consejo Supeior de Investigaciones científicas, 1977, pp.373-391.
}

Hist. Ensino, Londrina, v. 6, p. 11-32, out. 2000 
Blancard na ilha de Santo-Aleixo foi destruída e sua guarnição, massacrada de forma cruel. Três naus francesas que carregavam pau-brasil na baía de Todos os Santos foram afundados pela canhoneira de caravelas portuguesas e seus marinheiros enforcados ou enterrados vivos. Em retaliação, Jehan Ango pede ao rei uma Lettre de marque ${ }^{8}$ contra os lusos. Começava, em 1531, uma violenta repressão comercial capitaneada pelo audaz normando. Seus navios postavam-se próximos à ilha da Madeira e atacavam as caravelas, carregadas de mercadoria, vindas do Brasil. Ango nunca renunciou a comerciar com os indígenas americanos e estas trocas, mantidas a despeito de inúmeras dificuldades criadas por ambos os governos, ficaram registradas numa belíssima frisa de mármore que encontra-se hoje, no interior da igreja de são Tiago na cidade portuária de Dieppe, sede de suas atividades de mercador renascentista.

Um artista anônimo gravou em sete nichos pouco profundos, papagaios, homens e mulheres vestidos com penas, arcos, flechas à sombra de uma palmeira. Por trás de cada cena retratada esconde-se uma intenção que busca convencer, propondo ao seu observador uma correta compreensão do texto esculpido. Em seu conjunto, a frisa dos "selvagens" cristaliza uma história, uma propaganda, uma lição: um elogio ao presente e ao seu valor civilizador. O Renascimento era a época de todos os possíveis, de todas as audácias. O homem e, em nosso caso, Ango, o flibusteiro real, era o centro do mundo, lugar geométrico para o qual convergiam todos os humanistas. O otimismo era o seu lema, uma vez que o indivíduo era capaz de superar-se a si mesmo por meio de sua cultura, de sua educação e da época impressionante em que vivia. A frisa com imagens de índios brasileiros representa o tema caro ao Renascimento da diversidade da natureza. Com a dádiva desta obra de arte que

8 Cartas dadas pelo rei indicando a origem da esquadra e a bandeira sob a qual navegava. 
servia de testemunho de sua piedade e de seu prestígio frente à comunidade, Jean Ango, demonstrava como a diversidade, o Outro, o americano selvagem, podia aparecer como signo tangível da presença divina no mundo, testemunho da profusa generosidade do Criador face aos seus filhos. Os franceses assistiam a missa, mirando os longínquos selvagens, eles também filhos de Deus a espera da remissão dos pecados.

Ora, esta presença de Deus foi invocada para outras manifestações da presença francesa no Brasil. Num ilhéu da baía de Guanabara, chamado Serigipe, desembarcou, a 10 de novembro de 1555, Nicolau Durand de Villegagnon com seus companheiros. Cavaleiro da ordem de Malta, Villegagnon era senhor de uma vigorosa carreira militar tendo se batido contra os mouros, em Argel, contra os turcos em Malta, contra os ingleses na Escócia e contra os otomanos na Hungria. Sua idéia era de criar uma colônia pomposamente denominada de França Antártica, misto de empresa de colonização e de asilo onde, livres das perseguições que Ihes eram movidas na Europa, os adeptos da religião reformada pudessem exercer seu culto e suas práticas de sua fé.

O plano teve o apoio de Henrique II que, além de autorizar o envio de uma expedição francesa às costas brasileiras, confiou ao chefe da mesma, Villegagnon, duas boas e grandes naus devidamente carregadas com artilharia e munição e todo o material necessário para a construção de um forte. Endossado por armadores normandos e bretães, que viam a possibilidade de suas especulações mercantis transformarem-se numa colonização regular, o projeto ganhou a adesão de homens, curiosos e com vontade de construir, do outro lado do Atlântico, uma vida que fosse a réplica da que tinham na Europa. Numa jogada hábil, Villegagnon mostrou-se, de início, simpático à causa calvinista, cujos acólitos eram, então, perseguidos brutalmente, incitando-os a partir em direção ao continente cujas belezas naturais tanto lembravam o paraíso terreal. Tal apoio Ihe era, contudo, bastante comprometedor. Fora justamente o 
partido católico dominante que o apoiara, junto ao rei, na sua idéia de ter um pé francês em outras terras. Para contrabalançar, recrutou nas prisões de Paris, Ruão e outras cidades do reino, criminosos que quisessem completar a companhia das seiscentas pessoas que embarcaram do porto do Havre, em julho de $1555^{9}$.

Problemas? Muitos. Os embarcados eram homens sem família, ou que não levavam suas mulheres e entre eles estavam representados os mais diversos grupos sociais, cujas tensões também não era poucas. Uma vez desembarcados, não puderam contar com os índios da terra que desconheciam o hábito do labor continuado e sistemático para a edificação do forte batizado de Colligny. Temperaturas altas, sol causticante, febres e mazelas tropicais atacavam-nos sem trégua. As necessidades básicas de alimento, ao contrário do que se imaginara ao longo da viagem, também não eram satisfeitas. As frutas não cresciam ao pé das árvores, e quando as havia, havia igualmente a concorrência dos insetos e aves. Tudo estava por fazer e o desalento destes emigrados que sonhavam com abundância crescia a medida em que o pão era trocado por raízes, e o vinho, por água quase salobra. A faina era ininterrupta. Britar pedras, cortar toras, carregar terra, lutar contra os assaltos dos portugueses ou de tribos inimigas eram atividades diuturnas.

Um dos mais argutos observadores deste período foi um sapateiro, tornado pastor da Igreja de Genebra e que fora enviado por Calvino, aos 21 anos, para viver a experiência religiosa nos trópicos. Seu nome, Jean de Léry, autor, vinte anos depois de seu regresso à França, de uma História de uma viagem feita à terra do Brasil. Nesta obra, das primeiras a discorrer e descrever o Brasil para o olhar europeu, o autor relata o clima tenso entre as diversas facções de franceses que tinham vindo para a América, assim como as primeiras discussões teológicas havidas entre Villegagnon e os recém-chegados. $O$ tema do

9 Informações de Sérgio Buarque de Holanda, op.cit., p.149. 
debate era complexo: a eucaristia, a presença ou não de Cristo no singelo e místico pedaço de pão. Apaixonados, alguns militantes calvinistas acabaram rompendo com o chefe retornando á sua pátria, abrindo as primeiras brechas no plano de edificar aqui uma colônia francesa. Léry conta em primeira mão, o convívio com os índios tupiniquins cuja ferocidade era lendária mas que primava pela hospitalidade generosa e frugal com que prodigalizavam os franceses. Esses breves momentos passados no Éden irão lembrar-lhe, mais tarde ao voltar à Europa, a infância feliz da humanidade em meio a gente, que segundo o francês fugia da melancolia e da tristeza como o diabo da cruz. O canibal amava o riso. Foi esta imagem de alegria e brincadeira que ele levou de volta consigo, onze meses depois. Jamais esqueceu o cheiro da mandioca raspada, os ruídos da floresta tropical, as cores do céu e do mar. Ao encontrar uma Europa arruinada, soturna e ensangüentada por guerras fratricidas e religiosas, Léry registrou implacável: "Eu me arrependo de não estar entre os selvagens"10!

Não seria o único a manifestar desejo de viver entre os índios. Muitos franceses optaram por juntar-se com mulheres gentias com quem tinham filhos mestiços, a exemplo de tantos portugueses como João Ramalho, Diogo Álvarez e Jerônimo de Albuquerque. As mulheres não eram o única motivo das defecções. Muitos abandonavam a fortaleza na ilha de Serigipe por não suportar o ritmo de trabalho e as exigências moralistas de Villegagnon. Os índios, mostravam-se muito mais humanos do que os franceses da ilha. Os dissidentes instalaram-se em terra firme, formando uma pequena povoação ao pé do atual Morro da Viúva. Chamavam-na La briqueterie. Até que certo dia surgiu no horizonte um velho navio normando com o casco carcomido e a intenção de abastecer-se de pau brasil, pimenta,

\footnotetext{
10 Ver a introdução de Franck Lestringant à edição de Histoire d' un voyage en terre du Brésil, Paris, Entretien, 1994 e seu estudo sobre Léry, Le huguenot et le sauvage, Paris, Klincksieck, 1990).
}

Hist. Ensino, Londrina, v. 6, p. 11-32, out. 2000 
macacos, papagaios e outros produtos da terra. Alguns fugitivos pediram ao capitão que os transportassem de volta à França, mediante pagamento de algumas centenas de libras. Era o início do fim da França Antártica.

Com problemas no casco há poucas milhas do litoral a nau retornou. Os passageiros foram obrigados a desembarcar e voltar à ilha. De início Villegagnon os acolheu bem. Pouco depois, passou a desconfiar deste retorno e submeteu-os a um rigoroso questionário teológico. Seu medo era de que fossem a ponta de lança de um movimento de implementação do calvinismo na América. Aos mais ortodoxos condenou à morte por afogamento, pena imposta aos hereges na Europa. Dois outros, que the pareceram menos perigosos, foram poupados. $\mathrm{Na}$ França, estas notícias sobre dissidências teológicas no estabelecimento da Guanabara e seu desfecho trágico, com o sacrifício dos primeiros mártires calvinistas, provocaram uma reação em cadeia. O sistema de terror imposto no forte Colligny suscitou o maior descontentamento e reprovação entre as hostes protestantes. Mas isso não foi tudo. Os católicos também desconfiavam daquele a quem julgavam capaz de impor aos seus subordinados uma heresia nova, tão independente de Roma quanto de Calvino e Lutero ${ }^{11}$.

Nessas condições, conta-nos Sérgio Buarque de Holanda, pareceu melhor a Villegagnon embarcar para a Europa e defenderse desta e de outras imputações. Ora, para esta espécie de deserção precipitada não podia ter escolhido pior momento que este final de 1558. Os colonos que ainda restavam no Rio de Janeiro, desfalcados em número e coesão iam ficar à mercê dos terríveis maracajás, "o gentio do gato", amigos e aliados dos portugueses. Além disso, à tibieza de D. Duarte da Costa, o segundo governador-geral que assistiu impotente a intrusão dos franceses em terras da Coroa portuguesa, acabava de suceder a enérgica habilidade de Mem de Sá cujo propósito nevrálgico, desde que pisara em terras brasileiras, era só um: desalojar os franceses.

11 Apud Sérgio Buarque de Holanda, op.cit., pp.157-158. 
Em 1559 chegava à Bahia de Todos os Santos a armada sob o comando do capitão-mor Bartolomeu de Vasconcelos da Cunha, destinada a combater os papagaios amarelos na Guanabara. Apoiado nos jesuítas que já tinham lá seu colégio, o governador reuniu o maior número possível de índios que soubessem guerrear, o chamado "gentio de guerra". Ao mesmo tempo escreveu à capitânia de São Vicente, solicitando ajuda de homens e de armas. O encontro seria na barra do Rio de Janeiro a fim de juntar-se às forças metropolitanas que ai se encontravam. Mem de Sá pode contar, todavia, com a ajuda especial de um renegado francês. Jean Cointa, senhor de Boulés e doutor pela Sorbonne, um dos antigos acólitos de Villegagnon, era homem acostumado ao convívio com os índios aos quais se unira. Com eles, foi até São Vicente a pretexto de um ataque surpresa aos portugueses, aproveitando a oportunidade para passar-se para o outro lado. Foi imediatamente despachado para a Bahia onde deu, ao governador, notícias pormenorizadas das condições de defesa do forte Colligny, oferecendo-se mesmo para acompanhá-los no ataque que planejavam.

Sérgio Buarque de Holanda informa que havia várias dezenas de franceses na ilha: setenta e quatro homens com seus escravos, além de quarenta e um de um navio apresado e outros que andavam pela terra. Parte destes seriam intérpretes e aventureiros, remanescentes, em geral de antigas expedições que não tinham aceito a dura disciplina imposta aos colonos por Villegagnon. Do lado dos franceses estavam cerca de oitocentos ou mil índios aliados, segundo os cálculos do jesuíta Manuel da Nóbrega, um dos maiores entusiastas da expulsão dos protestantes. Do lado dos portugueses, havia dois mil e quinhentos homens bem armados, com o apoio de duas naus e oito embarcações menores. Dois dias e duas noites de luta aguerrida e o confisco da pólvora que havia no forte francês determinaram a vitória portuguesa, pondo fim a tentativa de ocupação e colonização da Guanabara ${ }^{12}$

12 Idem, p.160.

Hist. Ensino, Londrina, v. 6, p. 11-32, out. 2000 
Os contato entre franceses e índios tamoios contudo, não cessaram, por ai. Foram apenas transferidos para Cabo Frio. Mas foi face ao mar aberto e as areias luminosas desta localidade que teve lugar o pior massacre perpetrado pelos lusos aos seus contentores. Antônio de Salema, substituto de Mem de Sá e encarregado de governar as capitânias do sul esmagou cerca de dois mil e quinhentos combatentes entre índios e remanescentes dos franceses. Não deixou pedra sobre pedra, arrasando, inclusive, o forte que fora erguido como baluarte de proteção. Mais de setenta anos haviam se passado desde o naufrágio da nau de Jehan Ango nas costas do Brasil e até o final do século, escaramuças entre franceses e lusos foram constantes. Ataques a naus transportando autoridades e padres jesuítas com mortes e toda a sorte de brutalidades em retaliação aos maus tratos impingidos pelos portugueses, eram permanentes. Ágeis, quando perseguidos os franceses se moviam ao longo da costa transferindo, simplesmente, seus portos de carga e descarga de um ponto ao outro. Vez por outra eram pegos e aprisionados. Nomes como os de Jacques Postel, Jean Capdeville e Pain de Mil confirmam a fecundidade de tais contatos e a obstinação dos franceses de permanecer entre nós. Mas aonde ir?

A próxima tentativa de instalação francesa foi feita no Norte do Brasil, longe, portanto dos centros de poder e de vigilância da Metrópole. Ocorreu no Maranhão e recebeu o nome de França Equinocial. Por quê? Pois um cavaleiro bretão, Daniel de la Touche, o senhor de La Ravardière, tendo percorrido, no ano de 1604, as costas da Guiana, viu a possibilidade de fundar uma colônia "ao sul da linha equinocial", na embocadura do Amazonas, zona aparentemente abandonada e distante das plantações de cana que entretinham os portugueses. Apoiado por François de Razilly, cavaleiro bretão de alta extração e grande marinheiro, criou, com a anuência do rei Luís XIII, uma companhia colonizadora cujo objetivo era obter renda a partir do cultivo de terras e do comércio que se fizesse. Afinal, estas eram as afamadas terras do Eldorado, sede, no imaginário da época, das riquezas do Novo Mundo. Em julho de 1612, depois 
de cinco meses de viagem, cerca de quinhentos franceses despertaram frente às falésias verdes da sonolenta costa brasileira. Mais alguns dias de viagem e transpuseram a boca do Camocim, apreciaram a serra de lbiapaba até arribar na ilha de Maranhão ${ }^{13}$. Ai foram acolhidos por grande multidão de nativos que, segundo o costume, os saudavam com lágrimas: "Mal entramos na canoa e começaram os remeiros a remar em direção da terra, vimos maravilhados, inúmeros índios lançarem-se a nado para nos encontrar e trazer os seus agrados. E assim acompanhados chegamos, afinal, graças à bondade divina, ao lugar tão desejado", anotou um padre capuchinho, que acompanhava a comitiva para garantir a catequese dos americanos ${ }^{14}$.

Para construir a capela e a fortaleza escolheu-se um sítio distante légua e meia do ribeiro onde desembarcaram os viajantes: o Jeviré. Ai, com a ajuda dos índios, se ergueram também habitações de pindoba e um armazém. $O$ fortim foi guarnecido com vinte grandes canhões trazidos dos navios e se the deu o nome de São Luís. Dedicada ao orago de São Francisco, foi simultaneamente erguida uma capela e convento, feita de madeira, em sítio coberto de variadas árvores e regado por uma fonte de águas vivas que jorravam para o mar..$^{15}$ Posturas para a boa governação das novas terras foram impostas e tudo indica que tenham saído da pena dos padres capuchinhos. Cuidados espirituais ordenavam que se honrasse e respeitasse os sagrados mandamentos, o nome do Senhor e os reverendos padres. Homicídios eram punidos com morte exemplar, latrocínios com açoites e em caso de reincidência, estrangulamento. Os índios não podiam ser espancados ou injuriados. Estupradores e adúlteros eram igual e sumariamente mortos. Os que praticavam "atos desonestos por amor" com moça solteira, eram condenados a prestar serviços públicos durante trinta dias.

\footnotetext{
${ }^{13}$ Maurice Pianzola, op.cit., p.56.

${ }^{14}$ Claude d'Abbeville, História da Missão dos Padres Capuchinhos na ilha do Maranhão e terras circunvizinhas, São Paulo, EDUSP, Belo Horizonte, Itatiaia, 1975, p.55. 15 Sérgio Buarque de Holanda, "Os franceses no Maranhão", in op.cit., p.217.
} 
Tal como já ocorrera na Guanabara, alguns franceses mostraram-se logo refratários à vida na comunidade abandonando-a para ir residir nas aldeias indígenas que consentiam em acolhê-los ${ }^{16}$. Outros, que haviam sido seduzidos pelas promessas de viver em meio a uma terra onde brotavam esmeraldas, ouro e prata, confessavam-se ludibriados e tentavam desesperadamente voltar para ao Velho Continente. Em 1613, a recém fundada França equinocial já dava as primeiras mostras do cansaço que a corroía. Cioso dos problemas da comunidade, um dos seus dirigentes, o senhor de Rasilly, retornou à Paris, levando consigo um grupo de sete índios para exibir na Corte e convencer a família real de continuar amparando financeiramente o empreendimento. Quatro dentre eles morreram ao chegar. Vindos da ensolarada serra de Ibiapaba, não resistiram ao frio do inverno europeu. Os outros três foram batizados pelo cardeal de Paris, vestidos de tafetá branco e tendo na mão um lírio, símbolo da pureza. A festa que sucedeu ao sacramento, ao som de sarabandas, só não se realizou no palácio da princesa de Conti pois essa recusou-se a receber às mulheres que tinham sido acordadas aos índios, como "noivas": "As senhoras suas futuras esposas não eram outra coisa que...o senhor me entende?" explicava o poeta da Corte, François de Malherbe a um amigo ${ }^{17}$.

Depois de um ano na capital do reino francês, Razilly conseguiu enviar a São Luís consideráveis reforços: a bordo da nau expedicionária tinham embarcado nobres egressos de famílias prestigiosas, oficiais mecânicos de diversa especialidade e soldados, além de nova leva de padres capuchinhos. Os portugueses, contudo, sabedores da presença francesa no Maranhão não pareciam dispostas a obsequiar-Ihes com aquele pedaço de terra. Em julho de 1613, deixava Recife o mameluco Jerônimo de Albuquerque, levando provisão do governador geral

\footnotetext{
${ }^{16}$ idem, ibidem.

17 Apud Maurice Pianzola, op.cit.p.27.
} 
para a conquista do Maranhão. Os primeiros movimentos desta luta foram favoráveis aos franceses. Esses, contando com o apoio de índios da região, como "o Gregório de Guaxenduba", foram avisados da chegada sub-reptícia de soldados e frecheiros. Apesar da rápida reação gaulesa, prendendo patachos e inutilizando embarcações lusas com reforços, os portugueses conseguiram instalar-se num abrigo a que deram o nome de forte de Santa Maria. Daí, combateram sem trégua os recém-chegados da Corte francesa. Um escritor português que testemunhou os embates registrou que os luso-brasileiros, com água pela cintura "saltavam pelo lado como gamos, sendo que os inimigos como traziam meias e sapatos, e calções de pato tosado de vinte côvados de pano, em se metendo no lodo nele ficavam pegados e nele lhes quebravam as cabeças os nossos índios com paus"18

Coube a Sérgio Buarque de Holanda sublinhar que a superioridade dos que se batiam do lado português estava inscrita nos seus hábitos. Albuquerque o confirma ao escrever ao senhor de la Ravardière dizendo: "como somos homens que um punhado de farinha e um pedaço de cobra, quando os há, nos sustenta, quem a isto não se acomoda sempre há de recusar nossa companhia". Rudes e toscos, os luso-brasileiros acabaram vencendo essa gente mal habituada às guerras do Brasil, entendendo-se muito bem com os que haviam escapado à refrega. Os franceses, utilizaram-se de toda a "courtoisie que jamais français en serait faire" para sedimentar um tratado de trégua e a retirada do que restara de seus batalhão para São Luís. As hostilidades ficaram suspensas por uma ano, mas entre outubro e novembro de 1615 o forte de São Luís rendia-se com la Ravardière cercado por terra e mar. Seu algoz: Jerônimo de Albuquerque Maranhão.

Mas, finda a disputa pela ilha, o que aconteceu aos chefes dos papagaios amarelos? François de Razilly não esqueceu

${ }^{18}$ Apud Sérgio Buarque de Holanda, op.cit., p.229.

Hist. Ensino, Londrina, v. 6, p. 11-32, out. 2000 
jamais das praias e da gente maranhenses e encontrou-se, na Corte francesa, com seus camaradas de desventuras que the contaram os derradeiras peripécias passadas em São Luiz. Graças a seus esforços pessoais, um livro escrito pelo capuchinho Yves d'Evreux sobre a expedição brasileira, cuja tiragem malbaratara-se por fraude, foi recuperado, encadernado em marroquino e oferecido ao rei de França, Luís $\mathrm{XIII}^{19}$. Nomeado marechal de campo, depois embaixador na corte de Sabóia, Razzily tombou no cerco a cidade de Montpellier em mais um episódio das sangrentas guerras de religião que varriam a França.

Daniel de la Touche, senhor de la Ravardière, prisioneiro, primeiro em Olinda e mais tarde, três anos na torre de Belém em Lisboa, gozava de certas regalias. O rei não o fez se quer pagar impostos sobre as caixas de açúcar que transportara na bagagem vinda do Brasil. Seu interesse pela região era tão grande que não se furtou a requisitar às autoridades de Lisboa uma licença para enviar barcos a Pernambuco e à Bahia, a fim de continuar a fazer comércio. Depois de muitas idas e vindas entre os corpos diplomáticos de ambos os países, foi libertado. Curiosamente, corria na mesma época o boato de que preparava um ataque à capitania de Pernambuco de comum acordo com os holandeses. Livre, la Ravardière obtém do rei cartas patentes que renovaram seus poderes de tenente-general na América, Amazonas e Trinidad. Ele faleceu em 1635, na cidade de SaintMalo, sem contudo, sem dar, contudo, continuidade a seus projetos brasileiros ${ }^{20}$.

Enquanto franceses e luso-brasileiros querelavam pelo território maranhense, François Pyrard desembarcava, vindo das

\footnotetext{
19 Frère Yves d'Evreux, Voyage dans le Nord du Brésil fait pendant les années 1613 et 1614 ... publié d'aprés l'exemplaire unique conservé la Bibliothèque impériale de Paris, edição crítica de Ferdinand Denis, 1864. 20 Maurice Pianzola, op.cit., pp.196-198.
} 
Índias orientais, em Salvador ${ }^{21}$. Distante do entrechocar-se de armas, e das dificuldades enfrentadas por tantos dos seus, o viajante vai desfrutar de impressionante e tranqüila paisagem. As areias do litoral que avistara, antes de adentrar à baía de Todos os Santos, pareceram-lhe brancas como neve ou como lençóis. A cidade de São Salvador derramava-se suavemente encosta abaixo de uma colina, em cujo cimo erguia-se a catedral, o convento dos franciscanos e beneditinos, o colégio dos jesuítas. Ao pé do morro, casas habitadas por artesãos ladeavam a rua principal. Nas águas da baía, o viajante acompanhou "com prazer" a pesca de baleias e seu olhar não se cansava de observar as florestas, cujos galhos debruçavam-se, pontilhados de macacos, sobre o mar. O verde espesso e fechado da mata Atlântica Ihe parecia, todavia, inquietante e selvagem habitat de índios que apesar de batizarem-se diariamente nos conventos e igrejas locais, nada guardavam da docilidade dos gentios orientais, conservando-se "brutais".

Sua narrativa, minuciosa na descrição dos hábitos e mores da terra pode parecer, como bem diz Denis Crouzet ${ }^{22}$, uma invocação para que os franceses retomem consciência, depois do fracasso da França Antártica, da terra do Brasil. Ao deixar, em 1610, o Novo Mundo para trás, François Pyrard sublinha o que vai lhe parecer uma das características principais desta terra e de sua gente: é a capacidade de fazer surgir a riqueza e a abundância de uma terra selvagem. Ele discorre sobre a esperança humana nas obras divinas, uma esperança da qual o Brasil seria a mais acabada alegoria. Há em seu texto,

\footnotetext{
21 Seconde partie du Voyage de François Pyrard de Laval depuis l'arrivée à Goa jusques à son retour en France. Traite et description des animaux, arbres et fruits des Indes Orientales, observées par l'auteur. Plus un brief advertissement et avis pour ceux qui entreprennent le voyage des Indes. A Paris, chez Samuel Thiboust et Remy Dallier, 1615.

${ }_{22}$ Ver seu "À propos de quelques regards de voyageurs français sur le Brésil (vers 161-1720);entre espérance, malédiction et dégénérescence" in Naissance du Brésil Moderne,(org.) Kátia de Queiroz Mattoso, Centre d'Études sur le Brésil, Paris, Presses Universitaires de Paris-Sorbonne, 1998, pp.67-117.
}

Hist. Ensino, Londrina, v. 6, p. 11-32, out. 2000 
segundo o mesmo autor, um apelo para acreditar que fora dos mundos conhecidos, existiriam outros, desconhecidos, verdadeiros espaços de esperança, domínios, sim, cheios de perigos, mas igualmente plenos de promessas. $\mathrm{O}$ nascimento do Brasil, tal como ele será apresentado por Pyrard, participaria, nesta perspectiva, de uma glorificação de Deus através das obras e das crenças dos homens.

Até o final do século XVII, a Terra de Santa Cruz recebeu a visita de mais dois outros franceses que deixaram, eles também o registro de suas impressões. Pierre Moreau, em obra impressa em 1651, afirma ter passado dois anos no Brasil, tendo vindo numa frota holandesa encarregada de reabastecer Recife durante a guerra com os portugueses. Diferentemente dos viajantes que o precederam, ele não vê nem as maravilhas da natureza, nem a beleza do sítio ou tampouco a estética das igrejas. Sua visão é preenchida com imagens dramáticas que opõem portugueses e holandeses numa cidade sitiada pela fome. O seu olhar sobre o Brasil, como bem o diz Denis Crouzet $^{23}$, longe de vislumbrar um mundo saturado de vida ou um espaço em transformação graças as suas potencialidades, mais lhe parecia um universo morto habitado por fantasmas: "escravos e índios nus de corpos magros e secos como esqueletos, inspirando o mais certeiro terror"24. Em seu testemunho não se trata mais de reconhecer o Brasil edênico visitado por Léry, os franceses da França Equinocial e Pyrard de Laval. Invertem-se os esquemas mentais e a terra de felicidades encontra-se, não mais abaixo da linha do Equador, mas além mar, na distante e saudosa França. Aqui tudo era mal e desgraça e o risonho índio, antes descrito com simpatia pelo sapateiro calvinista, transformara-se, graças a pena de Moreau, em figura de pura crueldade à serviço dos malvados portugueses.

\footnotetext{
23 Idem, p.90.

24 Histoire des derniéres troubles de Brésil entre les hollandais et les portugais, a Paris, chez Augustin Courbis, 1651.p.125.
} 
O desapontamento do último visitante do século XVII, François Froger, também foi grande. Por ocasião de uma escala no Rio de Janeiro, o jovem viajante de 19 anos substituiu a impressão positiva sobre a paisagem por aquela, triste, a respeito dos habitantes. A entrada na baía de Guanabara se fizera, a princípio, ao som do canto de pequenos pássaros vindo das matas que desciam até o mar. O Pão de Açúcar a zelar sobre as águas calmas e navegáveis, a brisa vinda da terra, the indicava ter chegado a um lugar ideal para a navegação. A cidade estendia-se numa "bela planície" onde se destacavam as "riquíssimas" construções de beneditinos e jesuítas. Com preocupação de naturalista, Froger cataloga as culturas nascidas no terreno que the parecia tão fértil: cana, arroz, mandioca, milho, inhame, batata, banana, melão, laranja, goiabas e "outras das quais se fazia excelente compota". Tudo muda, contudo, ao falar da gente brasileira: "uma sociedade viciosa e corrompida" pois servida por escravos. $O$ fato de não se abaixar nem para pegar um alfinete, deixava os homens afeminados e moles. $O$ estereótipo reproduzido por vários viajantes que passaram pela América Latina é de que fornecendo mão de obra para todos os trabalhos domésticos, agrícolas ou outros, a escravidão tornava os colonos europeus preguiçosos, senhores de uma indolência corruptora de todas as virtudes. Roger vira tal corrupção de perto. Os brasileiros viveriam no luxo e no deboche e entre eles, os homens da Igreja eram os piores. Os religiosos tinham não somente licença para entreter suas mulheres públicas mas eram, segundo ele, possuidores de crassa ignorância ${ }^{25}$. A perversão destes que deveriam ser exemplares, - anotava alarmado poderia causar o "incêndio de uma nova Sodoma"26. A impressão do viajante ficava marcada pela repetição dos vícios decorrentes da escravidão e pela caricatura dos valores cristãos.

\footnotetext{
${ }^{25}$ Empesto aqui idéias a Denys Crouzet, op.cit., p.99.

${ }_{26}$ Relation d'un voyage fait en 1695,1696 et 1697 aux Cotes d'Afrique, detroit de Magellan, Brezil, Cayenne et Isles Antilles...A Paris, chez Nicolas le Gras, 1699.
} 
O Brasil visto e vivido pelos franceses entre os séculos XVI e XVII oscilou entre paraíso terreal e inferno, entre glória e miséria, entre grandeza e decadência. Sucessão de alegorias e de experiências constituiu-se numa aventura que fez recuar as margens da cristandade, estimular o florescimento do capitalismo europeu e inspirar os primeiros balbucios da etnografia . Laboratório da modernidade, o Brasil dos papagaios amarelos foi também campo de ensaio para vastas experiências religiosas, intelectuais e políticas desveladoras das múltiplas formas assumidas pela ocidentalização do mundo moderno, dos mecanismos e de objetivos dos quais somos herdeiros. Mas tal como uma estrada de mão dupla, as marcas deste fecundo convívio traduziram-se não somente em imagens de franceses sobre o Brasil mas também em imagens de brasileiros sobre o francês.

Esta espécie de visão nossa sobre o Outro, materializouse não por acaso no Nordeste em cujas praias os franceses estiveram por tantas vezes, e encontra-se, fecunda, na literatura de corde $^{27}$. Em mercados públicos como o de Currais Novos no Rio Grande do Norte, cegos esmolam cantando as aventuras de heróis louros, "amarelos" como os papagaios de outrora, na figura de Roldão, o Roland brasileiro cuja valentia resplandecente o levou a cair combatendo em Roncesvale há 1183 anos. Na feira do Alecrim de Natal o personagem cantado é Oliveiros, cuja espada, Durandal, tornou-se a popular durnindana. Nas cavalhadas de Maceió, o partido Encarnado é chefiado por nosso Roland e o Azul, por Oliveiros. A história fabulosa de Carlos Magno e de suas batalhas com Ferrabrás, a do imperador Balan ou os amores da princesa Floripes com o cavaleiro Guido de Borgonha e os sucessos dos doze pares de França eram lidos nas noites de inverno ou cantados em prosa e verso por nossos

27 Obrigatório sobre o assunto é o livro de Luís da Câmara Cascudo, Mouros, franceses e judeus, São Paulo, Perspectiva, 1984 de quem empresto algumas informações. Especialmente ao capítulo Roland no Brasil, pp.41-48. 
bardos sertanejos capazes, também, de comentar com minúcias as peripécias dramáticas de Amadis de Gaula.

"-Sei quem foi Roldão.

O duque Reguiné

E o duque de Milão

E o duque de Nemé

Sei quem foi Galalão,

Bonfim e Geraldo,

Sei quem foi Ricardo

E Gui de Borgonha,

Espada medonha

Alfanje pesado

- Já sei que o colega sabe

Deste acontecimento.

O que sofreu Carlos Magno,

Os seus enormes tormentos...

Talvez conheça dos Pares

Talvez algum casamento.

-Todos conquistaram pelejas cruéis, e aos infiéis

todos derrotaram; alguns se casaram com turca pagã pela fé cristã Roldão pela força Casou c'uma moça De Abderramã".

Enfim, os "papagaios amarelos" que os indígenas um dia viram arribar sobre as brancas praias de nossas costas, seguem vivos, valorosos e invencíveis na poesia do Nordeste do Brasil. 
Abstract: This text is about the visions produced by French explorers in their contact with Brazilian people and lands in the beginning of European colonization.

Keywords: Explorers, Brazil's History, Colonization, Representation 